\title{
MANAGEMENT BELIEFS AND PRACTICES OF ELEMENTARY SCHOOL HEADS ON INSTRUCTIONAL LEADERSHIP
}

\author{
Louie M. Buban ${ }^{1}$ and Gerry S. Digo ${ }^{1}$ \\ ${ }^{1}$ School of Graduate Studies, Sorsogon State University, Philippines
}

\section{ABSTRACT}

This study carry out a content analysis on the features of School Heads Development Program (SHDP) project outputs of school heads in the DepEd Schools Division of Sorsogon Province, Philippines. As part of the content analysis, the SHDP project outputs were categorized for instructional leadership. Also, the management beliefs and practices of school heads on instructional leadership along two-dimensional contracts were carry out in this study. The statistical tool used were Spearman and computed through the SPSS software program. The results were presented by frequencies in a descriptive way. The date collection technique was survey questionnaire and interview. The results indicated that the features were collegially done, generative, systematic, standardbased and shared manner. School heads' beliefs are strongly agreed and they frequently practiced instructional leadership. It can be concluded also that the management beliefs and practices of school heads on instructional leadership have significant relationship on communicating the school goals to conflict management as leadership process likewise, maintain high visibility to change process, meaning that school heads make use of leadership processes to perform well the instructional leadership function of an instructional leader.

Received 2 July 2021

Accepted 16 July 2021

Published 31 July 2021

Corresponding Author

Louie M. Buban, louie.buban09@g

mail.com

DOI $10.29121 /$

granthaalayah.v9.i7.2021.4088

Funding: This research received no specific grant from any funding agency in the public, commercial, or not-for-profit sectors.

Copyright: (C) 2021 The Author(s). This is an open access article distributed under the terms of the Creative Commons Attribution License, which permits unrestricted use, distribution, and reproduction in any medium, provided the original author and source are credited.

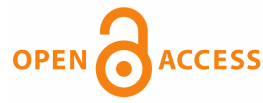

Keywords: Instructional Leadership, Management Beliefs, Management Practices, School Heads Development Program

\section{INTRODUCTION}

Instructional leadership of school heads plays a vital role in the teaching-learning process. The four corners of classroom are the place where teaching-learning process happens. It is the place where teachers deliver instructions efficiently and effectively for the growth of school children in every developmental stage since they are the center of the educative process. Also, it is where the school heads' role as instructional leader observed and performed.

School Heads evaluate the effectiveness of their teachers and improve the academic culture of the school. They eventually possess quality of leading the whole 
system of education. Their leadership skills encompass with assessment for learning, development and implementation, instructional supervision and technical assistance that school heads take or delegate to others to promote good teaching and higher-level learning among pupils/students "Deped Order No. 32 S. 2010. National Competency-Based Standards For School Heads From" (2010). One of the roles of the principal (school heads) focused toward the technical core responsibility of the school Peariso (2011), since the inception of "No Filipino Child Left Behind Act of 2010 " that the State shall protect and promote the right of the citizens to quality education and to take appropriate steps to make such education accessible to all. It states that the objectives and basic policy establishing for education focuses the establishment of rights, duties and responsibilities of those in the education system such as school administrators, teachers, non-academic staff, parents and school-children as it further regulates that education system of our country Plan (n.d.). And that, all Filipinos will be functionally literate by 2015 "Department Of Education Order No. 43 S" (2002). And this is expected when no pupil will be promoted to the next higher grade unless he or she manifest mastery of basic literacy skills in a particular grade level "Republic Act No. 9155" (n.d.). Therefore, school head shall be both an instructional leaders and administrative manager to take responsibility, authority and accountability "Basic Education Sector Reform Agenda" (n.d.). School heads' responsibilities anchored to the K-12 basic education program of the Department of Education which desires to offer a curriculum that is suited to the $21^{\text {st }}$ Century Hanlon (1981).

The deeply embedded beliefs and practices are a determinant of organizational effectiveness. Holding beliefs has great impact and influence how school heads perform in a specific task especially when it comes to leadership since their ultimate goals are to work with the school teachers/learning facilitators for delivery of quality educational programs, projects and services. Beliefs will aid them as a guiding compass especially when making big decisions where everybody will be benefited or negatively affected. For school heads, revealing their beliefs in every aspect of education, being the head of the school can make or break their reputation since many considered it sensitive issues to talk about in public.

To address the bewilderment on why some elementary school heads behave the way they wanted, the researcher examined the management beliefs and practices of the school heads especially on instructional leadership. The focus of this research was to find out the underlying beliefs of school heads on instructional leadership if these has connection on their leadership practices.

\section{MATERIALS AND METHODS}

\subsection{RESEARCH DESIGN}

The study put through content analysis on the features of School Heads Development Program (SHDP) project outputs. Content analysis as "a research technique for mak- 
ing replicable and valid inferences from texts (or other meaningful matter) to the contexts of their use" Krippendorff (2004). It is also more than counting process as the goal is to link the results to their context or to the environment in which they were produced: a systematic and objective means to make valid inferences from verbal, visual, or written data in order to describe and quantify specific phenomena DowneWamboldt (1992). To carryout, the researcher objectively analyzed the written data of the school heads from the categorized project outputs for instructional leadership. In addition, survey questionnaire and interview were utilized to determine the beliefs and practices of school heads. Spearman was computed using the SPSS (Version 27) software program to determine the correlation between the school heads management and beliefs.

\subsection{PARTICIPANTS}

The target group of this study are the 35 schools' districts of Department of Education Division of Sorsogon Province for SY 2020 - 2021. The study engaged 70 samples, school heads (35), and teachers (35). Every district represents one school head and teacher as respondent. They were chosen for a purposive-convenience sampling.

\subsection{TOOL}

The researcher utilized survey questionnaires, the Principal Instructional Management Rating Scale (PIMRS) which an adapted instrument designed by Dr. Philip Hallinger Hallinger and Murphy (1985). The instrument was scored in Likert-type scale. The instrument was scored in Likert-type scale. The instrument was categorized along the management beliefs with school heads respondents and management practices with teacher as respondents.

\section{RESULTS AND DISCUSSIONS}

\subsection{FEATURES OF SCHOOL HEADS DEVELOPMENT PROGRAM ANCHORED ON THE TWO-DIMENSIONAL CONSTRUCTS}

The features of School Heads Development Program on instructional leadership function along frame the school goals, communicating the school goals, developing high academic standards and expectations, and developing incentives for teachers and students have been done in a collegial manner. While, supervising and evaluating instructions was empirically done, coordinate the curriculum was standard-based, monitor students' progress was done in consistent and rigorous manner, and promoting professional development of teachers was done by support in mutual and shared manner. As to instructional leadership processes of school heads project outputs along communication was generative, decision-making and conflict management was collegially done through avoiding and compromising way, group process through consideration, change process was done through systematic approach, and 
environmental interaction through conciseness and carefulness.

\subsection{MANAGEMENT BELIEFS OF SCHOOL HEADS ON INSTRUCTIONAL LEADERSHIP ALONG WITH THE TWO-DIMENSIONAL CONSTRUCTS}

\begin{tabular}{ccc}
\hline Table 1 Management Beliefs of the School Heads on Instructional Leadership Functions \\
\hline Instructional leadership functions & $\begin{array}{c}\text { Average Weighted } \\
\text { Mean }\end{array}$ & Description \\
\hline Frame the school goals & 4.85 & Strongly agree \\
\hline Communicate the school goals & 4.83 & Strongly agree \\
Supervise and evaluate instruction & 4.73 & Strongly agree \\
\hline Coordinate the curriculum & 4.75 & Strongly agree \\
Monitor student progress & 4.81 & Strongly agree \\
Protect instructional time & 4.63 & Strongly agree \\
\hline Maintain high visibility & 4.49 & Agree \\
\hline Provide incentives for teachers & 4.85 & Strongly agree \\
Promote professional development & 4.79 & Strongly agree \\
Provide incentives for learning & 4.74 & Strongly agree \\
Grand Mean & 4.72 & Strongly agree \\
\hline
\end{tabular}

Table 1 shows the management beliefs of the school heads on instructional leadership functions. The computed grand weighted means on the management beliefs of the school heads on instructional leadership functions along frame the school goals, communicate the school goals, supervise and evaluate instruction, coordinate the curriculum, monitor student progress, protect instructional time, maintain high visibility, provide incentives for teachers, promote professional development and provide incentives for learning are 4.85, 4.83, 4.73, 4.75, 4.81, 4.63, 4.49, 4.58, 4.79, and 4.74 with a grand mean of 4.72 which described as strongly agree

Table 2 Management Beliefs of the School Heads on Instructional Leadership Processes

\begin{tabular}{ccc}
\hline Instructional leadership processes & Average Weighted Mean & Description \\
Communication & 4.65 & Strongly agree \\
\hline Decision-making & 4.46 & Agree \\
\hline Conflict management & 4.24 & Agree \\
Group process & 4.38 & Agree \\
Change process & 4.23 & Agree \\
Environmental interaction & 4.39 & Agree \\
Grand Mean & 4.39 & Agree \\
\hline
\end{tabular}

Table 2 shows the instructional leadership processes along communication, decision-making, conflict management, group, change, and environmental interaction are $4.65,4.46,4.24,4.38,4.23$, and 3.39 with a grand mean of 3.39 which described as agree. 


\subsection{MANAGEMENT PRACTICES OF SCHOOL HEADS ON INSTRUCTIONAL LEADERSHIP ALONG WITH THE TWO-DIMENSIONAL CONSTRUCTS}

Table 3 Management Practices of School Heads on Instructional Leadership Functions as Perceived by the Teachers

\begin{tabular}{|ccc|}
\hline Instructional leadership functions & $\begin{array}{c}\text { Average Weighted } \\
\text { Mean }\end{array}$ & Description \\
\hline Frame the school goals & 4.45 & Frequently \\
\hline Communicate the school goals & 4.31 & Frequently \\
\hline Supervise and evaluate instruction & 4.15 & Frequently \\
\hline Coordinate the curriculum & 4.19 & Frequently \\
\hline Monitor student progress & 4.29 & Frequently \\
\hline Protect instructional time & 4.03 & Frequently \\
Maintain high visibility & 3.98 & Frequently \\
Provide incentives for teachers & 4.01 & Frequently \\
\hline Promote professional development & 4.50 & Almost always \\
Provide incentives for learning & 4.34 & Frequently \\
Grand Mean & 4.23 & Frequently \\
\hline
\end{tabular}

Table 3 below shows that the computed grand weighted means on the management practices of the school heads as purely perceived by the teachers on instructional leadership functions along frame the school goals, communicate the school goals, supervise and evaluate instruction, coordinate the curriculum, monitor student progress, protect instructional time, maintain high visibility, provide incentives for teachers, promote professional development and provide incentives for learning are $4.45,4.31,4.15,4.19,4.29,4.03,3.98,4.01,4.50$, and 4.34 with a grand mean of 4.23 which described as frequently.

Table 4 Management Practices of School Heads on Instructional Leadership Processes as Perceived by the Teachers

\begin{tabular}{ccc}
\hline Instructional leadership processes & Average Weighted Mean & Description \\
Communication & 4.14 & Frequently \\
Decision-making & 4.11 & Frequently \\
Conflict management & 3.90 & Frequently \\
Group process & 3.95 & Frequently \\
Change process & 4.05 & Frequently \\
Environmental interaction & 4.11 & Frequently \\
Grand Mean & 4.04 & Frequently \\
\hline
\end{tabular}

Table 4 shows the instructional leadership processes along communication, decision-making, conflict management, group, change, and environmental interaction are $4.14,4.11,3.90,3.95,4.05$, and 4.11 with a grand mean of 4.04 which described as frequently. 


\subsection{RELATIONSHIP THAT EXISTS BETWEEN THE SCHOOL HEAD'S MANAGEMENT BELIEFS AND PRACTICES}

Table 5 Relationship between the School Head' Management Beliefs and Practices Instructional Leadership Functions

\begin{tabular}{|ccc|}
\hline Variable & Computed Values & Interpretation \\
\hline Frame the School Goals & 0.043 & Not Significant \\
\hline Communicate the school goals & 0.270 & Not Significant \\
\hline Supervise and evaluate Instruction & 0.120 & Not Significant \\
\hline Coordinate the curriculum & -0.016 & Not Significant \\
\hline Monitor student Progress & 0.115 & Not Significant \\
\hline Protect Instructional Time & -0.202 & Not Significant \\
\hline Maintain High Visibility & $.402^{*}$ & Significant \\
\hline Incentives for teachers & 0.141 & Not Significant \\
\hline Professional Development for Teachers & -0.047 & Not Significant \\
\hline
\end{tabular}

Table 5 shows that the computed statistical test values using the Spearman to determine the relationship between management beliefs and practices of the respondents in terms of Frame the School Goals, Communicate School Goals, Supervise and Evaluate Instruction, Coordinate the Curriculum, Monitor Student Progress, Protect instructional Time, Provide Incentives for Teacher, Promote professional Development, Provide Incentives for Learning are $0.043,0.270,0.120,-0.016,0.115,-0.202$, $0.141,-0.047,0.007$ and is less than/does not exceed critical value of 0.345 at 0.05 level of significance.

Table 6 shows that the computed statistical test values using the Spearman to determine the relationship between management beliefs and practices of the respondents in terms of communication, decision-making, conflict management, group process, change process, and environmental interaction are $-0.177,0.106,0.211,0.131$, -0.179 , and is less than/does not exceed critical value of 0.335 at 0.05 level of significance.

\begin{tabular}{ccc}
\hline \multicolumn{3}{l}{ Table 6 Relationship between the School Head's Management Beliefs and } \\
Practices Instructional Leadership Processes \\
\hline Instructional leadership processes & Computed Values & Description \\
Communication & -0.177 & Not Significant \\
\hline Decision-making & 0.106 & Not Significant \\
Conflict management & 0.211 & Not Significant \\
Group process & 0.131 & Not Significant \\
Change process & -0.179 & Not Significant \\
\hline Environmental interaction & 4.39 & Significant \\
\hline
\end{tabular}

In this study, there are five purposes established to explain the management beliefs and practices of school heads on instructional leadership. The first purpose established was to determine the features of School Heads Development Program 
(SHDP) project outputs of school heads anchored to the two-dimensional constructs of Hallinger and Murphy Hallinger and Murphy (1985). The features of school heads' accomplishment reports were analyzed through contextual analysis by textual presentation. It showed that the project outputs for leadership functions have been done in a collegial manner, standard based, consistent and rigorous manner. While, on leadership processes it was also done collegially, generative, and systematically.

The second purpose was to determine the management beliefs of school heads on instructional leadership along with the two-dimensional constructs perceived by themselves. The grand weighted mean for leadership function was obtained an equivalent to 4.72, which described as "Strongly Agree". While, on leadership processes the grand mean obtained 4.39, which has a description of "Agree". Based on the result, it means that school heads make good use of their position to process their duties and responsibilities as instructional leaders to improve the quality of education. One of the respondents stated that:

"Considering also the participation, collaboration and involvement of parents and stakeholders will help to the success of school since they are the partners in the educational process."

What people think, believe, and feel about themselves can affect their behavior in social settings Bandura (1997) Rashtchi (2021).

The third purpose was to determine the management practices of school heads on instructional leadership on two dimensional constructs as perceived by the teachers. The grand mean on leadership functions obtained 4.23 which described as "frequently". While, leadership processes garnered a grand mean of 4.04 described as "frequently". When asked, the respondent answered this way:

"School heads have lot of reports to be accomplished and other functions might be seldom neglected."

Likewise, other respondent gave thoughts in this way:

"Our school head rarely visit them for class observation due to other related activities but finds time to pay visits for formal class observation."

Leadership in an organization that is not appropriate will make employees unable to understand the direction of the leadership and management properly and will affect the results of the work shown by each of them Aisyah and Si (2021). However, one of the respondents commented this way:

"School head see to it that he's present as much as possible for important activities e.g., giving award to pupils' achievement."

Leadership is defined as a person's ability to be able to influence others, through communication, either directly or indirectly, with the intention of moving these people so that with understanding, awareness and pleasure, they are willing to follow the wills of the leader Anoraga (2003), Salain et al. (2021).

The fourth objective was to determine the relationship that exists between the school heads management beliefs and practices along with the identified variables. Based on the result, the computed statistical test values using the Spearman to deter- 
mine the relationship between management beliefs and practices of the respondents along instructional leadership functions is less than/does not exceed critical value of 0.345 at 0.05 level of significance with 33 degrees of freedom. This means that the management practices on instructional leadership of school heads does not affect their management beliefs on instructional leadership but they have strong impact or strongly influence each other. Since school heads are government employees; government employees are governed by Civil Service Commission Law, they are still entrenched by the belief and practice as stated by its rules and regulations. Whatever their beliefs in regards with their action is not affected by the practices in terms of school management because of the stated rules and regulations.

The fifth and last purpose was the intervention that could be proposed. Based from the result of the study, a Professional Development Plan for Elementary school heads in the Division of Sorsogon was hereby proposed.

\section{CONCLUSIONS AND RECOMMENDATIONS}

The instructional leadership of school heads are evident from the accomplishment reports of the project outputs for School Heads development Program (SHDP). It features are visible along the given variables. School heads have high regards on their beliefs on two-dimensional constructs. Almost all school heads believed and strongly agreed that the instructional leadership functions and processes are helpful in achieving good instructional leadership. But as perceived by the teachers, they frequently practiced their role as instructional leader along with the two-dimensional constructs. Teachers observed that school heads have many duties and responsibilities besides from being an instructional leader. There is no significant relationship between school heads management beliefs and practices in instructional leadership functions except maintain high visibility.

Since this study focuses only on the instructional leadership, further studies along management beliefs and practices of school heads in terms of two-dimensional constructs is hereby suggested. Future studies can also use different conceptual and theoretical framework along instructional leadership.

\section{REFERENCES}

Aisyah, S. E., \& Si, M. (2021). The Effect Of Planning And Leadership On Employee Performance In The Local Government Of The City Of Makassar. International Journal Of Innovative Science And Research Technology, 6(4).

Anoraga, P. (2003). Psikologi Kepemimpinan. Jakarta: Rineka Cipta.

Bandura, A. (1997). Self-Efficacy: The Exercise Of Control. Freeman.

Basic Education Sector Reform Agenda. (n.d.).

Batas Pambansa Blg. 232.Law. Phil. (n.d.). Retrieved from Https://Www.Lawphil.Net

Department Of Education Order No. 43 S. (2002).

Deped Order No. 32 S. 2010. National Competency-Based Standards For School Heads From. (2010). Retrieved from Http://Www.Depded.Gov.Ph 
Downe-Wamboldt, B. (1992). Content analysis: Method, applications, and issues. Health Care for Women International, 13, 313-321. Retrieved from https://dx.doi.org/10.1080/ $0739933920951600610.1080 / 07399339209516006$

Hallinger, P., \& Murphy, J. (1985). Assessing the Instructional Management Behavior of Principals. The Elementary School Journal, 86(2), 217-247. Retrieved from https://dx.doi .org/10.1086/461445 10.1086/461445

Hanlon, J. (1981). Theory Z In School ADM.

Krippendorff, K. (2004). Content Analysis: An Introduction To Its Methodology. Thousand Oaks, California: Sage Publications Inc.

Peariso, J. F. (2011). A Study Of Principals' Instructional Leadership Behaviors And Beliefs of Good Pedagogical Practice Among Effective California High Schools Serving Socioeconomically Disadvantaged And English Learners, Dissertation, Liberty University,Pdf.

Plan, E. (n.d.). Retrieved from Https://Depedtarlaccity.Com/EFA.Html

Rashtchi, M. (2021). Self-efficacy and Critical Thinking of Novice and Experienced EFL Teachers: A Sequential Mixed Methods Study. Pertanika Journal of Social Sciences and Humanities, 29(1), 1-25. Retrieved from https://dx.doi.org/10.47836/pjssh.29.1.01 10.47836/pjssh.29.1.01

Republic Act No. 9155. (n.d.). Retrieved from Https://Www.Officialgazette.Gov.Ph/2001/ 08/11/Republic-Act-No-9155/

Salain, P. P. P., Rismawan, P. E. A., Rihayana, G., Adhika, N. R., \& Manek, D. (2021). Effect Leadership, Organizational Culture And Information Technology On Employee Performance At Private Financial Services Companies In Denpasar City During The Covid-19 Pandemic. International Journal Of Innovative Science And Research Technology, 6(3). 